\title{
Efektifitas Terapi Murottal Al Qur'an terhadap Stres Mencit (Mus Musculus)
}

\author{
Meilina Ratna Dianti ${ }^{{ }^{*}}$ and Yen Yen Ari Indrawijaya ${ }^{1}$ \\ ${ }^{1}$ Program Studi Farmasi, Fakultas Kedokteran dan Ilmu Kesehatan, Universitas Islam Negeri Maulana Malik Ibrahim Malang \\ *E-mail: meilina@ farmasi.uin-malang.ac.id
}

\begin{abstract}
ABSTRAK
Stres merupakan suatu keadaan tertekan baik secara fisik maupun secara psikologis. Suatu proses yang menilai suatu peristiwa sebagai sesuatu yg mengancam, ataupun membahayakan dan individu merespon peristiwa itu pada level fisiologis, emosional, kognitif, dan perilaku. Hormon kortisol adalah hormon stres, karena hormon ini akan diproduksi lebih banyak saat tubuh mengalami stres baik fisik maupun emosional. Terapi murottal Al-Qur'an merupakan salah satu terapi non farmakologis yang dapat digunakan untuk mempercepat proses penyembuhan. Lantunan Al-Qur'an secara fisik mengandung unsur suara manusia. Suara dapat menurunkan hormon stres, mengaktifkan hormon endorfin alami, meningkatkan perasaan rileks dan mengalihkan perhatian dari rasa takut, cemas, dan tegang, memperbaiki sistem kimia tubuh. Surat Ar-Rahman merupakan surat Makiyah yang mempunyai karakter ayat pendek dan berulang sehingga dapat menimbulkan efek relaksasi bagi pendengar. Tujuan dari penelitian ini adalah Menganalisis efektifitas pemberian terapi Murottal Al Qur'an terhadap kadar hormon kortisol pada mencit yang mengalami stres. Metode penelitian ini adalah true experimental post-test only control group design. 35 mencit dibagi menjadi 5 kelompok, Kelompok K+: tidak diberi perlakuan murottal QS. Ar-Rahman dan tidak diberi paparan stresor kebisingan; Kelompok Kontrol (-) diberi paparan stresor kebisingan 21 hari dan tidak diberi perlakuan murottal QS. ArRahman; P1 diberi paparan stresor kebisingan 21 hari + murottal QS. Ar-Rahman 1 jam/hari; P2 diberi paparan stresor kebisingan 21 hari + murottal QS. Ar-Rahman 2 jam/hari; P3 diberi paparan stresor kebisingan 21 hari + murottal QS. ArRahman 4 jam/hari. Analisis data menggunakan Median Test didapatkan nilai $\mathrm{p}$ value adalah $0,032(\mathrm{p}<0,05)$ menyatakan terdapat perbedaan yang signifikan kadar kortisol pada mencit dengan kontrol negatif, kontrol positif dan yang mendapat perlakuan 1, 2, dan 3. Kesimpulan penelitian ini adalah bahwa Terapi Murottal Al Quran dapat menurunkan kadar kortisol mencit yang dipapar stres kebisingan.
\end{abstract}

Kata Kunci: Stres, Kebisingan, Murottal Al Quran, QS. Ar Rahman, Hormon, Kortisol

\section{Pendahuluan}

Stres adalah suatu kondisi dimana tuntutan yang harus dipenuhi melebihi kemampuan yang dimilikinya, penyebab stres dinamakan stresor. Stres dapat terjadi akibat ketidakmampuan seseorang dalam merespon suatu stresor, sehingga dapat mengakibatkan gangguan badan atau jiwa. Tubuh bereaksi terhadap stres dengan mengeluarkan 2 jenis zat kimia pembawa pesan yaitu hormon dalam darah dan neurotransmiter di sistem syaraf. Stres dapat didefinisikan sebagai kondisi dimana tuntutan yang harus dipenuhi melebihi kemapuan yang ada pada obyek. Stres tidak hanya terjadi pada tingkat organisme, melainkan juga terjadi pada tingkat organ dan sel. Stres merupakan bentuk reaksi tubuh yang menentukan kelangsungan kehidupan.
Era modernisasi seperti saat ini, stres menjadi bagian yang tidak dapat dipisahkan dari manusia [1]. Tingginya tingkat stres dapat dilihat dari data WHO (World Health Organization) pada tahun 2016 dimana sekitar 35 juta orang didunia mengalami stres. Stres adalah gangguan homeostasis yang menyebabkan perubahan pada keseimbangan fisiologis yang dihasilkan dari adanya rangsangan terhadap fisik maupun psikologis [2]. Stres dalam bentuk apapun adalah bagian dari kehidupan sehari-hari. Secara umum, stres terjadi jika individu dihadapkan dengan masalah, salah satunya peristiwa yang mereka rasakan sebagai ancaman kesehatan fisik atau psikologis [3].

Stres merupakan suatu keadaan tertekan baik secara fisik maupun secara psikologis. Suatu proses yang menilai suatu peristiwa sebagai sesuatu yg mengancam, ataupun 
membahayakan dan individu merespon peristiwa itu pada level fisiologis, emosional, kognitif, dan perilaku. Sesuatu didefinisikan sebagai peristiwa yang menekan atau tidak bergantung pada respon yang diberikan oleh individu terhadapnya. Suatu peristiwa atau pengalaman yang negatif sebagai sesuatu yang mengancam ataupun membahayakan dari situasi yang bersumber pada sistem biologis, psikologis dan sosial dari seseorang dapat memicu terjadinya stres.

Dr. Hans selye adalah orang pertama yang mengenali kesamaan respon terhadap berbagai rangsangan yang mengganggu, yang ia sebut sebagai syndrome adaptasi umum (General Adaptation Syndrome/General Stress Syndrome). Jika tubuh bertemu dengan stressor, tubuh akan mengaktifkan respon saraf dan hormon untuk melaksanakan tindakantindakan pertahanan untuk mengatasi keadaan darurat.

Faktor-faktor yang menyebabkan stres berasal dari rangsangan fisik, psikologis, atau dapat keduanya. Stres fisik disebabkan oleh exposure stressor yang berbahaya bagi jaringan tubuh misalnya terpapar pada keadaan dingin atau panas, penurunan konsentrasi oksigen, infeksi, luka / injuries, latihan fisik yang berat dan lama, dll. Sedangkan pada stres psikologis misalnya pada perubahan kehidupan, hubungan sosial, perasaan marah, takut, depresi dll. Jika tidak dapat mengatasinya dengan baik, dapat menyebabkan efek negatif baik pada kesehatan fisik maupun kesehatan mental. Sedangkan stres psikologis terdiri dari gejala kognisi, gejala emosi dan gejala tingkah laku. Masing-masing gejala tersebut mempengaruhi kondisi psikologis seseorang [4].

Menurut Hans Seley, seorang ahli fisiologi dan pakar stres menyatakan bahwa stres adalah suatu respon tubuh yang tidak spesifik terhadap aksi atau tuntutan atasnya. Stres merupakan respon automatic tubuh yang bersifat adaptif pada setiap perlakuan yang menimbulkan perubahan fisik atau emosi yang bertujuan untuk mempertahankan kondisi fisik yang optimal suatu organisme. Reaksi fisiologis ini disebut sebagai General Adaptation Syndrome (GAS) [5].

Dari sudut pandang psikologis stres didefinisikan sebagai suatu keadaan internal yang disebabkan oleh kebutuhan psikologis tubuh, atau disebabkan oleh situasi lingkungan atau sosial yang potensial berbahaya memberikan tantangan, menimbulkan perubahan atau memerlukan mekanisme pertahahanan seseorang [5]. Stres akan mempengaruhi homeostasis tubuh melalui dua jalur, yaitu sumbu HPA (Hipotalamus Pituitary Adrenal) dan sumbu simpatik. Stres akan menstimulasi HPA dan simpatik untuk menghasilkan hormon kortisol dan kotekolamin [6].

Hormon kortisol atau juga dikenal secara luas sebagai hormon stres, karena hormon ini akan diproduksi lebih banyak saat tubuh mengalamai stres baik fisik maupun emosional. Saat merasa terancam maka bagian dari otak akan menyalakan alaram tubuh. Hal tersebut akan memicu kelenjar adrenal mengeluarkan hormon adrenalin bersamaan dengan hormon kortisol. Hormon adrenalin akan meningkatkan detak jantung, sementara hormon kortisol yang dikenal sebagai hormon stres akan meningkatkan gula dalam darah, sehingga otak dapat bekerja lebih efektif.

Dalam keadaan normal, hormon stres dilepaskan dalam jumlah kecil sepanjang hari, tetapi bila menghadapi stres kadar hormon ini meningkat secara dramatis [7]. Setiap jenis respon tubuh yang berupa stres, baik stres fisik maupun stres psikis dapat meningkatkan sekresi ACTH yang pada akhirnya dapat meningkatkan kadar kortisol, awal pelepasan hormon stres dimulai dengan sekresi Corticotropin Releasing Factor (CRF). Pertama kali CRF dilepaskan dari hipotalamus diotak kealiran darah, sehingga mencapai kelenjar pituitary yang berlokasi tepat dibawah hipotalamus. Ditempat ini CRF merangsang pelepasan ACTH oleh pituitary yang pada gilirannya akan merangsang kelenjar adrenalis untuk melepaskan berbagai hormon salah satunya adalah kortisol. Kortisol beredar di dalam tubuh dan berperan dalam mekanisme koping. Bila stresor yang diterima hipotalamus kuat, maka CRF yang disekresi akan meningkat, sehingga rangsang yang diterima oleh pituitary juga meningkat dan sekresi kortisol oleh kelenjar adrenal juga meningkat. Apabila kondisi emosional telah stabil, mekanisme koping menjadi positif, maka sinyal diotak akan menghambat pelepasan CRF dan siklus hormon stres berulang lagi. Dalam kondisi gelisah, cemas, dan depresi sekresi kortisol meningkat.

Terapi murottal Al-Qur'an merupakan salah satu terapi nonfarmakologis yang dapat digunakan untuk mempercepat proses penyembuhan [8]. Hal ini telah dibuktikan oleh Ahmad Al-Qadhi yang melakukan penelitian dengan tema pengaruh Al-Qur'an pada manusia dalam perspektif fisiologi dan psikologi. Penelitian tersebut menunjukkan hasil positif bahwa mendengarkan ayat suci Al-Qur'an memiliki pengaruh yang signifikan dalam menurunkan ketegangan urat syaraf reflektif [9].

Murottal adalah rekaman suara Al-Qur'an yang dilagukan oleh seorang qori' (pembaca Al-Qur'an). Lantunan Al-Qur'an secara fisik mengandung unsur suara manusia. Suara dapat menurunkan hormon stres, mengaktifkan hormon endorfin alami, meningkatkan perasaan rileks dan mengalihkan perhatian dari rasa takut, cemas, dan tegang, memperbaiki sistem kimia tubuh [10]. Salah satu surat dalam Al-Qur'an yang berfungsi sebagai syifa' dan dapat digunakan sebagai terapi murottal adalah surat Ar-Rahman [11]. Surat Ar-Rahman yang berarti Yang Maha Pemurah, merupakan surat ke 55 didalam Al-Qur'an dan terdiri dari 78 ayat. Semua ayat dalam surat Ar-Rahman merupakan surat Makiyah yang mempunyai karakter ayat pendek sehingga ayat ini nyaman 
didengarkan dan dapat menimbulkan efek relaksasi bagi pendengar [12]. Alunan surat Ar-Rahman merdu jika pembacaannya tartil (sesuai dengan aturan pembacaan AlQur'an yang benar). Surat Ar-Rahman juga memiliki banyak ayat yang dibaca berulang-ulang sehingga mampu memberikan penekanan/penegasan alunan suara bagi pendengarnya. Kalimat yang dibaca berulang-ulang dapat mengalihkan perhatian dan berfungsi sebagai hipnosis, sehingga gelombang otak pasien akan menurun jika mendengarkannya, dalam keadaan ini otak memproduksi hormon serotonin dan endorfin yang menyebabkan seseorang merasa nyaman, tenang, dan Bahagia.

Berapa penelitian mengenai kortisol telah dilakukan, mengemukakan bahwa murottal Al-Qur'an dapat menurunkan tekanan darah pada penderita hipertensi primer [13], terapi murottal Ar-Rahman dapat menurunkan intensitas nyeri pada pasien post operasi sectio Caesar [15]. Serta mendengarkan murottal Al-Qur'an berpengaruh terhadap penurunan tingkat insomnia [14]. Belum ada penelitian terhadap efektivitas terapi murottal Al-Qur'an terhadap stres sehingga peneliti tertarik untuk melakukan penelitian pada mencit yang diberi perlakuan stres terlebih dahulu.

\section{Materials and Methods}

\subsection{Jenis dan Rancangan Penelitian}

Penelitian ini merupakan penelitian eksperimental laboratorik dengan rancangan penelitian true experimental post-test only control group design. Sampel hewan coba mencit jantan galur balb/c diberi paparan stresor kebisingan yang menyebabkan terjadinya stres pada mencit kemudian diberi terapi non farmakologi murottal Al-Quran.

\subsection{Waktu dan Tempat Penelitian}

Penelitian akan dilaksanakan selama 6 bulan. Penelitian ini dilakukan di Laboratorium Biomedik Jurusan Farmasi UIN Maulana Malik Ibrahim Malang.

\subsection{Sampel Penelitian}

Sampel yang digunakan pada penelitian ini adalah hewan coba mencit jantan. Jenis mencit yang digunakan adalah mencit (Mus musculus) berjenis kelamin jantan galur balb/c. Adapun kriteria inklusi yang digunakan dalam penelitian ini yaitu: (1) Berjenis kelamin jantan, (2) Usia sekitar 8-12 minggu, (3) Keadaan sehat yang ditandai dengan bergerak aktif, (4) Berat badan rata-rata 20-40 gram, (5) Tidak mempunyai kelainan anatomi. Adapun kriteria eksklusi pada penelitian ini yaitu (1) Mencit yang mati pada saat masa pemberian perlakuan.

\subsection{Prosedur Penelitian}

Ethical Clearence. Sebelum dilakukan penelitian terhadap hewan coba, maka dilakukan terlebih dahulu ethical clearence oleh Komite Etik dan Penelitian Kesehatan (KEPK) Fakultas Kedokteran dan Ilmu Kesehatan Universitas Islam Negeri Maulana Malik Ibrahim Malang.

Tahap Persiapan Hewan Coba. Hewan coba diadaptasikan terlebih dahulu di dalam lingkungan kandang di Laboratorium Biomedik Jurusan Farmasi UIN Maulana Malik Ibrahim Malang selama satu minggu diletakkan dalam kandang dengan dibagi setiap kelompok perlakuan dan diberi makan dan minum setiap hari ad libitum.

Tahap Perlakuan Hewan Coba. Mencit sebanyak 35 ekor dibagi menjadi 5 kelompok perlakuan dan kontrol masingmasing 7 ekor, yaitu:

1. Kontrol (+) : Kelompok kontrol positif (tidak diberi perlakuan terapi murottal Al-Quran Surat Ar-Rahman dan tidak diberi paparan stresor kebisingan)

2. Kontrol (-) : Kelompok Kontrol negative diberi paparan stresor kebisingan 21 hari dan tidak diberi perlakuan terapi murottal Al-Quran Surat Ar-Rahman

3. (P1) : Kelompok Perlakuan 1 (paparan stresor kebisingan 21 hari + terapi murottal Al-Quran Surat Ar-Rahman 1 jam per hari)

4. (P2) : Kelompok Perlakuan 2 (paparan stresor kebisingan 21 hari + terapi murottal Al-Quran Surat Ar-Rahman 2 jam per hari)

5. (P3) : Kelompok Perlakuan 3 (paparan stresor kebisingan 21 hari + terapi murottal Al-Quran Surat Ar-Rahman 4 jam per hari)

Tahap Pemberian Stresor Kebisingan. Kelompok kontrol atau perlakuan yang diberi paparan stresor kebisingan masingmasing kandangnya diputarkan suara bising jalan raya melalui speaker yang memiliki volume diatas $85 \mathrm{~dB}$ selama 12 jam dalam 21 hari dimulai pukul 18.00-06.00 WIB. Menurut intensitas kebisingan $>85 \mathrm{~dB}$ merupakan wujud batas dengar tertinggi dari kondisi jalan raya yang hiruk pikuk.

Tahap Pemberian Terapi Murottal Al-Quran. Kelompok perlakuan yang telah diberikan paparan stresor kebisingan dilanjutkan dengan pemberian terapi non farmakologi murottal Al-Quran Surat Ar-Rahman dimulai pada pukul 10.00 WIB selama 1 jam pada kelompok perlakuan pertama (P1), 2 jam pada kelompok perlakuan kedua (P2) dan 4 jam pada kelompok perlakuan ketiga (P3) menggunakan speaker yang telah diatur sedemikian rupa hingga masa perlakuan selama 21 hari dengan volume dibawah $60 \mathrm{~dB}$. 
Tahap Pengambilan Sampel. Pemeriksaan sampel darah dilakukan setelah tahap perlakuan berakhir yaitu pada hari ke21. Tahapan awal yang dilakukan adalah Semua peralatan yang akan digunakan dibersihkan terlebih dahulu menggunakan alkohol 70\%. Langkah berikutnya mencit diambil dari kandang dan dianastesi dengan kloroform $70 \%$ kemudian dilakukan fiksasi.

Tahap Pengambilan Sampel Darah. Pengambilan darah hewan coba dilakukan secara intrakardial. Pembedahan dilakukan hingga organ jantung terlihat lalu darah diambil secara intrakardial menggunakan disposible syringe sebanyak $\pm 1 \mathrm{cc}$. Darah yang telah diambil dimasukkan ke dalam tabung vacutainer yang telah dibersihkan. Setelah itu, tabung yang berisi darah dikocok agar tidak terjadi lisis kemudian disentrifus dan diambil lapisan darah teratas.

Tahap pengukuran kadar kortisol. Serum yang telah dipisahkan dipipet dan dimasukkan ke dalam microtube, diberi tanda dan disusun dalam rak microtube. Pemeriksaan kadar dilakukan segera setelah pengambilan sampel. Seluruh sampel kemudian disimpan dalam cooler box untuk menjaga kestabilan sampel sebelum diukur menggunakan ECLIA (Electrochemiluminescence immunoassay).

\section{Results and Discussion}

\subsection{Pengujian Asumsi One-Way Analisis Of Variace} (ANOVA)

ANOVA dapat dilakukan jika data memenuhi asumsi normalitas dan homogenitas data. Oleh karena itu terlebih dahulu dilakukan uji normalitas data dengan menggunakan metode Saphiro-Wilk test. Metode ini digunakan untuk menganalisis apakah data tersebut menyebar mengikuti distribusi normal atau tidak. Uji homogenitas data dilakukan menggunakan levene's test. Metode ini digunakan untuk menganalisis apakah data penelitian memiliki keragaman yang identik. Apabila salah satu asumsi pada ANOVA tidak tercapai maka pengujian hipotesis akan digantikan dengan uji non-parametrik pengganti One-Way ANOVA yaitu uji statistik non-parametrik Median Test. uji Median Test merupakan pengujian statistik non-parametrik yang digunakan untuk menguji perbedaan tiga atau lebih objek/perlakuan dengan variabel ukur merupakan data nominal atau ordinal atau data interval maupun rasio yang tidak memenuhi asumsi normalitas. Median Test sangat mirip dengan ANOVA perbedaan dasarnya adalah parameter yang diuji merupakan median sedangkan ANOVA lebih diinterpretasikan pada perbedaan rata-rata.

Uji Asumsi Normalitas. Pengujian asumsi normalitas dilakukan dengan menggunakan uji saphiro-wilk. Adapun Hipotesis yang berlaku untuk uji normalitas data pada ANOVA dapat dijelaskan sebagai berikut :

H0 : Data penelitian menyebar mengikuti sebaran normal

H1: Data penelitian tidak menyebar mengikuti sebaran normal

Hipotesis yang diharapkan adalah menerima hipotesis H0 atau menolak hipotesis $\mathrm{H} 1$ yaitu variabel yang diamati mengikuti sebaran normal. Hipotesis $\mathrm{H} 0$ diterima apabila nilai signifikansi untuk setiap variabel lebih besar dari alpha $5 \%$.

Tabel 4.1. Hasil Pengujian Normalitas Saphiro-Wilk Tests of Normality

\begin{tabular}{cccc}
\hline & \multicolumn{3}{c}{ Shapiro-Wilk } \\
\cline { 2 - 4 } & Statistic & df & Sig. \\
\hline $\begin{array}{c}\text { Kadar } \\
\text { Kortisol }\end{array}$ & .853 & 25 & .002 \\
\hline
\end{tabular}

Uji normalitas pada data kadar hormon kortisol pada mencit dapat dilihat pada tabel 4.1. hipotesis dari data ditentukan melalui nilai signifikansi yang diperoleh, dimana $\mathrm{H}_{0}$ adalah data berdistribusi normal. $\mathrm{H}_{0}$ diterima bila nilai signifikansi $>0,05$. Berdasarkan hasil analisis dapat diperoleh bahwa untuk data kadar hormon kortisol pada mencit dalam penelitian ini diperoleh nilai signifikansi saphiro-wilk < 0,05, sehingga $\mathrm{H}_{0}$ ditolak, dan dinyatakan bahwa data kadar hormon kortisol pada mencit dalam penelitian ini tidak menyebar mengikuti distribusi normal.

Uji Asumsi Homogenitas. Uji homogenitas ragam adalah sebuah uji untuk melihat apakah variabel yang diteliti mempunyai ragam yang homogen antar kelompok umur atau tidak. Metode yang digunakan dalam pengujian ini yaitu meode Levene. Adapun hipotesis dalam pengujian homogenitas dapat diuraikan sebagai berikut:

Ho : kelompok perlakuan dalam data penelitian memiliki ragam yang homogen

H1 : kelompok perlakuan dalam data penelitian memiliki ragam yang tidak homogen

Hipotesis yang diharapkan adalah menerima hipotesis $\mathrm{H}_{0}$ atau menolak hipotesis $\mathrm{H}_{1}$ yaitu variabel yang diamati mempunyai ragam yang homogen antar perlakuan. Hipotesis $\mathrm{H}_{0}$ diterima apabila nilai signifikansi untuk setiap variabel lebih besar dari alpha $5 \%$. 
Tabel 4.2. Hasil Pengujian Homogenitas Ragam Levene

\begin{tabular}{cccc}
\hline \multicolumn{4}{c}{ Test of Homogeneity of Variances } \\
\hline \multicolumn{4}{c}{ Kadar Kortisol } \\
\hline $\begin{array}{c}\text { Levene } \\
\text { Statistic }\end{array}$ & df1 & df 2 & Sig. \\
\hline $\mathbf{2 . 0 4 2}$ & 4 & 20 & .127 \\
\hline
\end{tabular}

Hasil uji homogenitas ragam pada variabel kadar hormon kortisol pada mencit dapat dilihat pada tabel 4.2. Pengujian hipotesis dari data ditentukan melalui nilai signifikansi yang diperoleh. $\quad \mathrm{H}_{0}$ diterima bila nilai signifikansi $>0,05$. Berdasarkan hasil analisis dapat diperoleh bahwa untuk variabel kadar hormon kortisol pada mencit nilai signifikansi $>0,05$, maka $\mathrm{H}_{0}$ diterima, berarti untuk data kelompok perlakuan pada variabel kadar kortisol dalam penelitian ini memiliki ragam yang homogen.

Berdasarkan hasil uji asumsi normalitas didapatkan bahwa baik pada variabel kadar hormon kortisol pada mencit tidak memenuhi asumsi normalitas, sedangkan pada uji homogenitas ragam didapatkan variabel kadar hormon kortisol pada mencit memenuhi asumsi homogenitas ragam. Hasil uji asumsi menunjukkan bahwa kadar hormon kortisol pada mencit tidak memenuhi keseluruhan asumsi untuk ANOVA. Dengan demikian untuk variabel kadar hormon kortisol pada mencit, uji beda dilakukan dengan menggunakan uji median test sebagai pengganti one-way ANOVA apabila asumsi ANOVA tidak terpenuhi.

Hasil Median Test. Uji median test merupakan uji pengganti One-Way ANOVA apabila asumsi pada ANOVA tidak terpenuhi. Hipotesis yang digunakan pada uji median test sama seperti pada ANOVA, adalah sebagai berikut :

$\mathrm{H}_{0}$ : Tidak terdapat perbedaan median kadar kortisol pada masing-masing kelompok mencit

$\mathrm{H}_{1}$ : Terdapat perbedaan median kadar kortisol pada masingmasing kelompok mencit.

Kriteria penolakan $\mathrm{H}_{0}$ yaitu apabila nilai p-value (signifikansi) hasil uji median test $<(\alpha)=0,05$ (5\%). Adapun hasil pengujian median test pada kadar kortisol pada mencit dalam penelitian ini dijelaskan pada tabel 4.3 berikut

Tabel 4.3 Hasil Pengujian Median Test pada Kadar Kortisol

\begin{tabular}{|c|c|c|}
\hline Hipotesis & Signifikansi & Keterangan \\
\hline 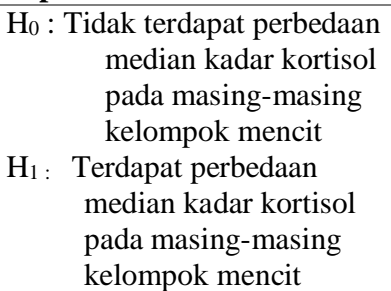 & 0,032 & Berbeda Nyata \\
\hline
\end{tabular}

Berdasarkan uji median test hipotesis ditentukan dari nilai signifikansi yang diperoleh. Dimana Ho diterima bila nilai signifikansi > 0.05 dan $\mathrm{H} 1$ diterima bila nilai signifikansi $<0.05$. Berdasarkan tabel uji median test pada kadar kortisol mencit dengan kontrol negatif, kontrol positif dan perlakuan 1, 2, dan 3 didapatkan nilai signifikansi 0,032 ( $\mathrm{p}<0,05$ ), maka berarti terdapat perbedaan yang signifikan kadar kortisol pada mencit dengan kontrol negatif, kontrol positif dan yang mendapat perlakuan 1, 2, dan 3. Karena ditemukan terdapat perbedaan yang signifikan pada kadar hormon kortisol pada mencit dengan kontrol negatif, kontrol positif dan yang mendapat perlakuan 1, 2, dan 3, maka dilakukan uji lanjut untuk mengetahui perbedaan kadar kortisol mencit pada masing-masing perlakuan digunakan uji moses.

Uji multikomparasi post-hoc moses bertujuan untuk mengetahui perbedaan masing - masing kelompok pada respon yang diamati. Perbedaan kelompok dianggap bermakna apabila $\mathrm{p}<0,05$. Ringkasan uji moses ditampilkan pada tabel berikut :

Tabel 4.4. Ringkasan Nilai Signifikansi (p) Uji Moses Pada Respon Kadar Kortisol

\begin{tabular}{cccccc}
\hline Perlakuan & K(-) & $\mathbf{K}(+)$ & P1 & P2 & P3 \\
\hline $\mathbf{K}(-)$ & - & 0,738 & $0,000^{*}$ & $0,000^{*}$ & $0,000^{*}$ \\
\hline $\mathbf{K}(+)$ & 0,738 & - & 0,500 & 0,738 & 0,500 \\
\hline P1 & $0,000^{*}$ & 0,500 & - & 0,738 & 0,897 \\
\hline P2 & $0,000^{*}$ & 0,738 & 0,738 & - & 0,976 \\
\hline P3 & $0,000^{*}$ & 0,500 & 0,897 & 0,976 & - \\
\hline
\end{tabular}

Keterangan : * = berbeda signifikan

Hasil pengujian pada tabel 4.4 kemudian dapat disederhanakan untuk mempermudah membaca hasil analisis. Tabel 4.5 menunjukkan hasil penyederhanaan pengujian moses yang telah dilakukan

Tabel 4.5. Hasil Uji Lanjut Respon Kadar Hormon Kortisol

\begin{tabular}{ccc}
\hline Konsentrasi & Median & Notasi \\
\hline Kontrol (-) & 13,36 & $\mathrm{~A}$ \\
\hline Kontrol (+) & 11,64 & $\mathrm{Ab}$ \\
\hline Perlakuan 1 & 7,62 & $\mathrm{~B}$ \\
\hline Perlakuan 2 & 7,61 & $\mathrm{~B}$ \\
\hline Perlakuan 3 & 4,50 & $\mathrm{~B}$
\end{tabular}

Keterangan : notasi huruf yang berbeda menunjukkan adanya perbedaan yang signifikan antar perlakuan

Berdasarkan hasil uji lanjut pada tabel 4.5 dapat diketahui bahwa terdapat perbedaan nilai median kadar hormon kortisol pada tikus yang tidak diberikan stres dan tidak diberikan treatment (murottal) dengan tikus yang diberikan stres dan diberi perlakuan (murottal) baik treatment murottal 1, 2, atau 4 jam. Lainnya halnya pada tikus yang 
diberikan stres dan tidak diberikan treatment yang ternyata tidak berbeda signifikan dengan tikus yang tidak diberikan stres dan tidak diberikan treatment (murottal) dan juga tikus yang diberikan stres dan diberi perlakuan (murottal) baik treatment murottal 1, 2, atau 4 jam. Secara keseluruhan penelitian ini juga menunjukkan adanya penurunan kadar kortisol seiring bertambahnya waktu treatment yang dilakukan hal ini juga mengindikasikan semakin lama tikus yang stres diperdengarkan murottal maka tingkat kadar hormon kortisol akan semakin rendah.

Stres adalah suatu kondisi dimana tuntutan yang harus dipenuhi melebihi kemampuan yang dimilikinya, penyebab stres dinamakan stresor. Stres dapat terjadi akibat ketidakmampuan seseorang dalam merespon suatu stresor, sehingga dapat mengakibatkan gangguan badan atau jiwa. Tubuh bereaksi terhadap stres dengan mengeluarkan 2 jenis zat kimia pembawa pesan yaitu hormon dalam darah dan neurotransmiter di sistem syaraf. Stres dapat didefinisikan sebagai kondisi dimana tuntutan yang harus dipenuhi melebihi kemapuan yang ada pada obyek. Stres tidak hanya terjadi pada tingkat organisme, melainkan juga terjadi pada tingkat organ dan sel. Stres merupakan bentuk reaksi tubuh yang menentukan kelangsungan kehidupan.

Dari sudut pandang psikologis stres didefinisikan sebagai suatu keadaan internal yang disebabkan oleh kebutuhan psikologis tubuh, atau disebabkan oleh situasi lingkungan atau sosial yang potensial berbahaya memberikan tantangan, menimbulkan perubahan atau memerlukan mekanisme pertahahanan seseorang [5]. Stres akan mempengaruhi homeostasis tubuh melalui dua jalur, yaitu sumbu HPA (Hipotalamus Pituitary Adrenal) dan sumbu simpatik. Stres akan menstimulasi HPA dan simpatik untuk menghasilkan hormon kortisol dan kotekolamin.

Dari penelitian yang telah dilakukan didapatkan hasil bahwa terdapat penurunan kadar hormon kortisol pada mencit dengan waktu treatmen yang berbeda. Semakin lama mencit stres diperdengarkan Murottal Al Quran maka kadar hormon kortisol juga semakin menurun. Hal ini membuktikan bahwa Murottal Al-Quran dapat menenangkan mencit yang stres, serta menurunkan kadar stres mencit yang ditandai dengan penurunan kadar hormon kortisol.

Hormon kortisol atau juga dikenal secara luas sebagai hormon stres, karena hormon ini akan diproduksi lebih banyak saat tubuh mengalamai stres baik fisik maupun emosional. Saat merasa terancam maka bagian dari otak akan menyalakan alaram tubuh. Hal tersebut akan memicu kelenjar adrenal mengeluarkan hormon adrenalin bersamaan dengan hormon kortisol. Hormon adrenalin akan meningkatkan detak jantung, sementara hormon kortisol yang dikenal sebagai hormon stres akan meningkatkan gula dalam darah, sehingga otak dapat bekerja lebih efektif.

Dalam keadaan normal, hormon stres dilepaskan dalam jumlah kecil sepanjang hari, tetapi bila menghadapi stres kadar hormon ini meningkat secara dramatis [7]. Setiap jenis respon tubuh yang berupa stres, baik stres fisik maupun stres psikis dapat meningkatkan skresi ACTH yang pada akhirnya dapat meningkatkan kadar kortisol, awal pelepasan hormon stres dimulai dengan skresi corticotropin releasing factor (CRF). Pertama kali CRF dilepaskan dari hipotalamus diotak kealiran darah, sehingga mencapai kelenjar pituitary yang berlokasi tepat dibawah hipotalamus. Di tempat ini CRF merangsang pelepasan ACTH oleh pituitary yang pada gilirannya akan merangsang kelenjar adrenalis untuk melepaskan berbagai hormon salah satunya adalah kortisol. Kortisol beredar di dalam tubuh dan berperan dalam mekanisme koping. Bila stresor yang diterima hipotalamus kuat, maka CRF yang disekresi akan meningkat, sehingga rangsang yang diterima oleh pituitary juga meningkat dan sekresi kortisol oleh kelenjar adrenal juga meningkat. Apabila kondisi emosional telah stabil, mekanisme koping menjadi positif, maka sinyal diotak akan menghambat pelepasan CRF dan siklus hormon stres berulang lagi. Dalam kondisi gelisah, cemas, dan depresi sekresi kortisol meningkat [16].

Terapi murottal Al-Qur'an merupakan salah satu terapi nonfarmakologis yang dapat digunakan untuk mempercepat proses penyembuhan [8]. Hal ini telah dibuktikan oleh Ahmad Al-Qadhi yang melakukan penelitian dengan tema pengaruh Al-Qur'an pada manusia dalam perspektif fisiologi dan psikologi. Penelitian tersebut menunjukkan hasil positif bahwa mendengarkan ayat suci Al-Qur'an memiliki pengaruh yang signifikan dalam menurunkan ketegangan urat syaraf reflektif [9]. Murotal adalah rekaman suara Al-Qur'an yang dilagukan oleh seorang qori' (pembaca Al-Qur'an). Lantunan Al-Qur'an secara fisik mengandung unsur suara manusia. Suara dapat menurunkan hormon stres, mengaktifkan hormon endorfin alami, meningkatkan perasaan rileks dan mengalihkan perhatian dari rasa takut, cemas, dan tegang, memperbaiki sistem kimia tubuh [10].

Salah satu surat dalam Al-Qur'an yang berfungsi sebagai syifa' dan dapat digunakan sebagai terapi murottal adalah surat Ar-Rahman [11]. Surat Ar-Rahman yang berarti Yang Maha Pemurah, merupakan surat ke 55 didalam Al-Qur'an dan terdiri dari 78 ayat. Semua ayat dalam surat Ar-Rahman merupakan surat Makiyah yang mempunyai karakter ayat pendek sehingga ayat ini nyaman didengarkan dan dapat menimbulkan efek relaksasi bagi pendengar [12]. Alunan surat Ar-Rahman merdu jika pembacaannya tartil (sesuai dengan aturan pembacaan Al-Qur'an yang benar). Surat ArRahman juga memiliki banyak ayat yang dibaca berulang- 
ulang sehingga mampu memberikan penekanan/penegasan alunan suara bagi pendengarnya. Kalimat yang dibaca berulang-ulang dapat mengalihkan perhatian dan berfungsi sebagai hipnosis, sehingga gelombang otak pasien akan menurun jika mendengarkannya, dalam keadaan ini otak memproduksi hormon serotonin dan endorfin yang menyebabkan seseorang merasa nyaman, tenang, dan Bahagia.

\section{Kesimpulan}

Pemberian terapi murottal Al Qur'an Surat Ar Rahman dapat menurunkan kadar kortisol mencit yang dipapar stres suara kebisingan hiruk pikuk jalan raya.

\section{Daftar Pustaka}

[1] Dharmayanti, A.W.T. 2012. Pengaruh Stresor Renjatan Listrik pada Kadar Kolesterol Total pada Serum Tikus Jantan (Rattus norvegicus) Strain Wistar. J.K.G Unej. Vol. 9(1). P: 01.

[2] Dewe, P.J., and Cooper, C.L. 2012. Theories of Psychological Stress at Work. USA: Springer. P: 2328.

[3] Andria. 2015. Pengaruh Stres Terhadap Kadar Hormon Progesteron pada Tikus Wistar Postpartum. Jurnal Maternity and Neonatal. 2 (1). P.1-7

[4] Milosevi'c, V., S. Trifunovi'c, M. Sekuli'c, B. Sosi'cJurjevi'c, B. Filipovi'c, N. Negi'c, N. 2005. Chronic Exposure to Constant Light Affects Morphology and Secretion of Adrenal Zona Fasciculata Cells in Female Rats, Gen. Physiol. Journal Biophys. 2(4). P. 299-309.

[5] Nursalam, 2007. Asuhan Keperawatan Pada Pasien Terinfeksi HIV dan AIDS. Jakarta: Salemba Medika

[6] Desai, S.K., Sonlye,M.D., Navdeep,S., Arya, P., Pooja, T. 2011. Antistress Activity of Boerhhavia diffusa root extract and a polyherbal formulation containing boerhaavia diffusa using cold restraint stress models, International Journal of Pharmacy and Pharmaceuticsl Science. 3(1). P: 130-132.

[7] Stocker S. 2012. Studies Link Stress and Drug Addiction. NIDA Research Finding 14:1-4

[8] Haesodo, A. (2008). Kajian klinis musik sebagai alat terapi kesehatan. Diperoleh tanggal 26 November 2014 http://www.ajihoesodo.com/index.php?option=com_c ontent $\&$ task $=$ view \&id $=32 \&$ Itemid $=45$

[9] Remolda, P. (2009). Pengaruh Al-Qur'an pada manusia dalam perspektif fisiologi dan psikologi. http://www.theedc.com. Tanggalakses: 14-11-2014

[10] Heru. (2008). Ruqyah syari'I berlandaskan kearifan lokal. Diperoleh tanggal 30 November 2014 dari http://trainermuslim.com/feed/rss

[11] Salim, S.A. 2012. Ensiklopedi Pengobatan Islam. Solo: Pustaka Arafah

[12] Srihartono. (2007). Aayaatul bayyinaat: Tanda-tanda kebesaran allah lalqur'an yang jelas dan terang. Jakarta: Pustaka Nawaitu.

[13] Pratiwi, dkk. 2015. Pengaruh Teknik Relaksasi Benson dan Murottal al-Qur'an Terhadap Tekanan Darah Pada Penderita Hipertensi Primer. JOM Vol. 2 No. 2

[14] Wulandari, dkk. Mendengarkan Murattal Al-Qur'an Untuk Menurunkan Tingkat Insomnia. Jurnal Intervensi Psikologi Vol.7 No.1 Juni 2015

[15] Apriliana, dkk. 2014. Pengaruh Terapi Murotal Ar Rahmaan Terhadap Penurunan Intensitas Nyeri Pada Pasien Post Operasi Caesar Di RSUD Prof. Dr. Margono Soekarjo Purwokerto. Jurnal Viva Medika: Vol. 07 No. 12

[16] Bear MF, Barry WC, Michael AP. 1996. Neuroscience: Exploring The Brain. Baltimore: Williams \& Wilkins. 403-412. 